\title{
KEMACETAN LALU LINTAS DI KAWASAN TLOGOSARI SEMARANG
}

\author{
Anisa Kurniati \\ Universitas Semarang; JI Soekarno Hatta Semarang \\ Email : anisaakurniati85@gmail.com
}

\begin{abstract}
ABSTRAK
Infrastruktur merupakan suatu pembangunan fasilitas berupa fisik maupun non fisik yang sengaja dibangun untuk menujang kebutuhan masyarakat baik itu secara sosial maupun perekonomian, salah satu bentuk dari infrastruktur adalah pembangunan jalan, di mana jalan itu juga identik dengan kemacetan khususnya pada wilayah kota-kota besar maupun daerah yang memiliki aktivitas penduduk yang cukup padat. Kawasan Tlogosari Semarang merupakan kawasan yang sering terjadi kemacetan, di karenakan para pengguna jalan lebih banyak menggunakan kendaraan pribadi daripada kendaraan umum, sehingga hal tersebut juga bisa memicu kemacetan karena jumlah kendaraann yang padat, ditambah lagi faktor-faktor lain yang menyebabkan kawasan ini sering macet terlebih pada jam berangkat dan pulang kerja. Identifikasi pada penelitian ini menggunakan metode penelitian kualitatif dengan hasil penelitian yang membuktikan terdapat tiga faktor utama kemacetan tersebut yakni karena wilayah Kawasan Tlogosari Semarang merupakan wilayah yang cukup strategis, sebagai salah satu pusat perdagangan dan jasa, serta merupakan kawasan pendidikan.
\end{abstract}

Kata Kunci : Kemacetan, Kawasan, Jalan

\section{ABSTRACT}

Infrastructure is a construction of facilities in the form of physical and non-physical that is intentionally built to support the needs of the community both socially and economically, one form of infrastructure is road construction, where the road is also synonymous with congestion, especially in large cities and regions. which has a fairly dense population activity. The Tlogosari area of Semarang is an area that often gets traffic jams, because road users use private vehicles more than public transportation, so that it can also trigger congestion due to the dense number of vehicles, plus other factors that cause this area to often get jammed especially on the way to and from work. The identification in this study uses qualitative research methods with research results that prove there are three main factors of the congestion, namely because the Tlogosari area of Semarang is a strategic area, as a center of trade and services, and is an educational area.

Keyword: Congestion, Area, Road

\section{PENDAHULUAN}

Infrastruktur merupakan bentuk pembangunan fasiilitas untuk keperluan publik dan memudahkan kehidupan masyrakat dalam melakukan aktivitas sosial maupaun ekonomi. Oleh karena itu pembangunan infrastuktur merupakan pembangunan yang cukup penting untuk memajukan sebuah kota. Seperti Infrastruktur dalam sebuah sistem adalah bagianbagian berupa sarana dan prasarana (jaringan) yang tidak terpisahkan satu sama lain ( Grigg, 1988 ).

Salah satu kategori infrastruktur adalah infrastruktur jalan. Infrastruktur jalan merupakan prasarana yang berperan penting dalam pembangunan sebuah kota. Namun terdapat beberapa permasalahan yang sering terjadi pada infrastruktur jalan yaitu kemacetan. Kemacetan biasanya terjadi di daerah kota-kota besar seperti Kota Semarang, tepatnya pada sekitar kawasan Tlogosari Semarang. 
Penyebab kemacetan di Perumahan Tlogosari adalah persimpangan lima di sebagai arus di persimpangan Jalan Soekarno Hatta-Tlogosari-Supriyadi-Medoho, Kota Semarang sering terjadi penumpukan dan PKL di kawasan Tlogosari menempati badan jalan termasuk untuk pedagang bermobil sehingga menimbulkan kemacetan (Yolanda dan Kartono, 2014; Imanda dan Rusdarti, 2020; Susilo, 2019).

Kawasan Tlogosari termasuk kawasan yang sering terjadi kemacetan karna di sekitarnya terdapat beberapa sarana pendidikan mulai dari SD sampai perguruan tinggi. Selain itu sering macet karna di Tlogosari merupakan kawasan perdagangan dan jasa yang tentukan padat akan aktivitasnya sehingga menyebabkan kemacetan.

Oleh karena permasalahan tersebut perlunya untuk meidentifikasi penyebab terjadinya kemacetan tersebut, dengan menggunakkan metode penelitian kualitatif permasalahan tersebut bisa mendapatkan solusi yang sesuai dengan kondisi kawasannya.

\section{DATA DAN METODE}

\subsection{Pendekatan}

Pendekatan ini menggunakan metode kualitatif, penelitian kualitatif lebih cocok digunakan untuk jenis penelitian yang memahami tentang fenomena sosial dari perspektif partisipan. Secara sederhana, dapat pula diartikan sebagai penelitian yang lebih cocok digunakan untuk meneliti kondisi atau situasi si objek penelitian (Sugiono, 2005).

Metode ini digunakan untuk mencari informasi yang ada di lokasi menggunakan observasi lapangan, dengan cara meidentifikasi sesuai dengan keadaan yang ada di lokasi yang ingin di teliti.

\subsection{Pengumpulan data}

Pengumpulan data pada penelitian ini terbagi menjadi beberapa bagian, pengumpulan data di gunakan sebagai cara untuk menggambarkan hasil data yang diperoleh di lapangan maupun melalui analisis dokumen. Adapaun metode pengumpulan data tersebut, yaitu :

1. Observasi

Data ini diperoleh dengan cara langsung mengamati kondisi eksisting yang ada di lapangan, yaitu dengan mengamati situasi kemacetan yang terjadi.

2. Dokumentasi

Teknik pengumpulan data ini digunakan untuk memdokumentasikan hasil observasi berupa foto yang diperoleh dari hasil lapangan. 
Selain itu terdapat juga pengumpulan data yang diperoleh dari BPS setempat untuk melengkapi hasil identifikasi yang dilakukan.

\subsection{Metode Analisis}

Pada penelitian ini metode yang digunakan ialah metode analisis deskriptif kaulitatif, metode ini digunakan untuk mengambarkan kondisi di wilayah yang akan diteliti, hasil yang diperoleh dari metode analisis ini berupa uraian ataupun narasi yang menjelaskan keadaan yang ada di lokasi penelitian.

\section{HASIL DAN PEMBAHASAN}

Kawasan Tlogosari Semarang merupakan suatu daerah letaknya berada di Kecamatan Pedurungan. Berbatasan langsung dengan Kecamatan Genuk di sebelah utara, berbatasan dengan Kecamatan Tembalang di sebelah selatan, berbatasan dengan Kecamatan Gayamsari di sebelah barat, dan berbatasan dengan Kabupaten Demak di sebelah timur.

Kecamatan Pedurungan memiliki 12 kelurahan, dengan data menurut BPS setempat jumlah rukun tetangga (RT) berada pada Kelurahan Tlogosari Kulon yakni merupakan salah satu kawasan yang padat akan aktivitas penduduknya, terdiri dari $251 \mathrm{RT}$ dan $28 \mathrm{RW}$. Dengan jumlah tersebut tidak heran jika kawasan Tlogosari sering mengalami kemacetan lalu lintas.

Jika dilihat dari segi permukaan Kecamatan Pedurungan memiliki permukaan yang dikategorikan datar 100\%, dengan ketinggian sekitar 4-7 meter di atas permukaan laut. Pada tahun 2019, Kecamatan Pedurungan mengalami laju pertumbuhan penduduk sebesar 0,97\%. Kelurahan dengan laju pertumbuhan penduduk tertinggi berada di Kelurahan Pedurungan Lor yaitu sebesar 3,53\%.

Laju pertumbuhan penduduk yang cukup tinggi juga menyebabkan aktivitas kegiatan lalu lintas menjadi padat dan sering terjadi kemacetan, selain itu faktor kondisi jalan terutama panjang jalan dan jenis permukaan jalan juga mempengaruhi kelancaran lalu lintasnya. Berikut ini akan ditampilkan tabel panjang jalan menurut kecamatan dan jenis pernukaan jalan di Kota Semarang, yaitu : 
Vol 26 No 2 Tahun 2021

Tabel 1. Panjang Jalan Menurut Kecamatan dan Jenis Permukaan Jalan di Kota Semarang

\begin{tabular}{|l|l|l|l|l|}
\hline Kecamatan & Aspal & Beton & Kerikil & Tanah \\
\hline Mijen & 50,86 & 21,37 & 2,15 & 1,62 \\
\hline Gunungpati & 68,12 & 15,42 & 0,00 & 0,00 \\
\hline Banyumanik & 58,67 & 8,45 & 0,20 & 0,00 \\
\hline Gajah Mungkur & 30,97 & 0,00 & 0,00 & 0,00 \\
\hline Semarang Selatan & 40,42 & 3,23 & 0,00 & 0,25 \\
\hline Candisari & 22,11 & 0,00 & 0,00 & 0,00 \\
\hline Tembalang & 53,55 & 41,68 & 2,83 & 0,20 \\
\hline Pedurungan & 25,66 & 40,61 & 0,00 & 0,00 \\
\hline Genuk & 6,97 & 46,66 & 1,21 & 11,32 \\
\hline Gayamsari & 14,64 & 9,88 & 0,58 & 0,07 \\
\hline Semarang Timur & 15,61 & 16,21 & 0,40 & 0,00 \\
\hline Semarang Utara & 0,41 & 35,87 & 1,65 & 1,30 \\
\hline Semarang Tengah & 33,76 & 19,67 & 0,00 & 0,00 \\
\hline Semarang Barat & 43,12 & 18,08 & 0,00 & 3,66 \\
\hline Tugu & 4,20 & 11,99 & 0,00 & 1,79 \\
\hline Ngaliyan & 41,87 & 9,94 & 0,65 & 0,00 \\
\hline
\end{tabular}

Sumber : BPS Kota Semarang, 2020

Dari tabel di atas dapat disimpulkan bahwa Kecamatan Pedurungan memiliki panjang jalan sekitar 25,66 km dengan jenis permukaan dari aspal dan 40,61 km dengan jenis permukaan beton. Kecamatan Pedurungan merupakan salah satu kecamatan yang memiliki akses jenis jalan yang memadai karna hampir semua kawasannya terutama Kawasan Tlogosari tidak memiliki jalan yang berupa kerikil ataupun tanah, semuanya sudah lebih baik karna sudah di aspal maupun beton. Hal ini membuktikan bahwa kawasan Tlogosari termasuk unggul dalam ketersediaan akses prasarana jalannya.

Selain panjang jalan dan jenis permukaan jalan, sarana angkutan yang tersedia juga dapat mempengaruhi seberapa padat kemacetan di daerah tersebut. Berikut dibawah ini akan di tampilkan tabel banyaknya sarana angkutan di Kecamatan Pedurungan pada tahun 2018, yaitu: 
Vol 26 No 2 Tahun 2021

Tabel 2. Banyaknya sarana angkutan di Kecamatan Pedurungan pada tahun 2018

\begin{tabular}{|l|c|c|c|c|}
\hline Kelurahan & Sepeda & Dokar & Songkro & Becak \\
\hline Gemah & 540 & 3 & 3 & 75 \\
\hline Pedurungan Kidul & 528 & 5 & 0 & 17 \\
\hline Plamongsari & 2,358 & 0 & 0 & 6 \\
\hline Penggaron Kidul & 354 & 3 & 0 & 41 \\
\hline Pedurungan Lor & 350 & 0 & 0 & 150 \\
\hline Tlogomulyo & 258 & 0 & 0 & 3 \\
\hline Pedurungan Tengah & 650 & 0 & 0 & 82 \\
\hline Palebon & 2,586 & 0 & 0 & 45 \\
\hline Kalicari & 562 & 0 & 0 & 23 \\
\hline Tlogosari Kulon & 8,865 & 0 & 0 & 21 \\
\hline Tlogosari Wetan & 1,352 & 0 & 5 & 5 \\
\hline Muktiharjo Kidul & 3,856 & 0 & 0 & 75 \\
\hline
\end{tabular}

\begin{tabular}{|l|c|c|c|c|}
\hline \multicolumn{1}{|c|}{ Kelurahan } & Sepeda motor & Mobil Pribadi & Taxi & Mobil Dinas \\
\hline Gemah & 2,001 & 184 & 0 & 23 \\
\hline Pedurungan Kidul & 775 & 145 & 0 & 0 \\
\hline Plamongsari & 2,350 & 81 & 0 & 3 \\
\hline Penggaron Kidul & 1,421 & 135 & 0 & 0 \\
\hline Pedurungan Lor & 1,545 & 135 & 400 & 12 \\
\hline Tlogomulyo & 1,995 & 19 & 0 & 3 \\
\hline Pedurungan Tengah & 10,299 & 2,099 & 0 & 0 \\
\hline Palebon & 2,157 & 365 & 0 & 25 \\
\hline Kalicari & 550 & 88 & 0 & 5 \\
\hline Tlogosari Kulon & 6,578 & 485 & 0 & 15 \\
\hline Tlogosari Wetan & 707 & 98 & 0 & 0 \\
\hline Muktiharjo Kidul & 5,466 & 460 & 15 & 30 \\
\hline
\end{tabular}

\begin{tabular}{|l|c|c|c|c|}
\hline \multicolumn{1}{|c|}{ Kelurahan } & Colt & Angkutan & Truk & Bus \\
\hline Gemah & 0 & 0 & 47 & 0 \\
\hline Pedurungan Kidul & 0 & 12 & 15 & 5 \\
\hline Plamongsari & 0 & 6 & 12 & 0 \\
\hline Penggaron Kidul & 2 & 20 & 18 & 2 \\
\hline
\end{tabular}


Vol 26 No 2 Tahun 2021

\begin{tabular}{|l|c|c|c|c|}
\hline \multicolumn{1}{|c|}{ Kelurahan } & Colt & Angkutan & Truk & Bus \\
\hline Pedurungan Lor & 20 & 4 & 13 & 2 \\
\hline Tlogomulyo & 0 & 0 & 0 & 0 \\
\hline Pedurungan Tengah & 0 & 0 & 532 & 0 \\
\hline Palebon & 0 & 10 & 0 & 2 \\
\hline Kalicari & 0 & 0 & 4 & 0 \\
\hline Tlogosari Kulon & 0 & 0 & 35 & 0 \\
\hline Tlogosari Wetan & 0 & 5 & 1 & 0 \\
\hline Muktiharjo Kidul & 9 & 10 & 5 & 0 \\
\hline
\end{tabular}

Dari tabel di atas dapat disimpulkan bahwa sarana angkutan yang lebih dominan ada di jalan sekitar Kawasan Tlogosari adalah berupa sepeda motor dan mobil pribadi yang jumlahnya lebih banyak daripada jumlah angkutan lainnya. Dan kelurahan yang jumlah penggunanya paling besar ada di Keluarahan Pedurungan Tengah dengan jumlah sekitar 10,299 kendaraan. Dari data diatas dapat dipastikan bahwa penyebab kemacetan di Kawasan Tlogosari karna kurangnya penggunaan angkutan umum serta masyarakat sekitar lebih memilih banyak yang menggunakan kendaraan pribadi daripada angkutan umum tersebut misal seperti bus dan lainnya. Untuk sarana penunjang angkutan umum Kecamatan Pedurungan memiliki satu terminal terletak di daerah Penggaron Kidul.

Adapun tiga faktor utama yang menjadikan Kawasan Tlogosari sering mengalami kemacetan, yaitu sebagai berikut :

- Lokasi

Dari segi lokasi, Kawasan Tlogosari merupakan kawasan yang cukup strategis karena terletak tidak jauh dari jalan arteri yang pastinya selalu ramai dilalui oleh para pengguna jalan yang melewatinya, di jam-jam tertentu keadaan lalu lintas pun selalu macet karna padatnya akan aktivitas masyarakat setempat. Seperti dijam-jam berangkat kerja sekitar jam 7 atau jam 8 pagi Kawasan Tlogosari sering macet dan di jam pulang kerja sekitar jam 4 sore atau 5 sore juga pasti macet dibeberapa titik. Terutama di lampu merah arteri Soekarno Hatta, titik kemacetan di daerah itu karena lampu merah tersebut menghubungkan jalan arteri dengan jalan yang padat aktivitas kegiatan masyarakat sekitar, seperti jalan Tlogosoari raya 1 yang merupakan pusat perdagangan dan jasa serta dan jalan Supriyadi yang biasanya juga sering mengalami kemacetan di jam jam tertentu. 


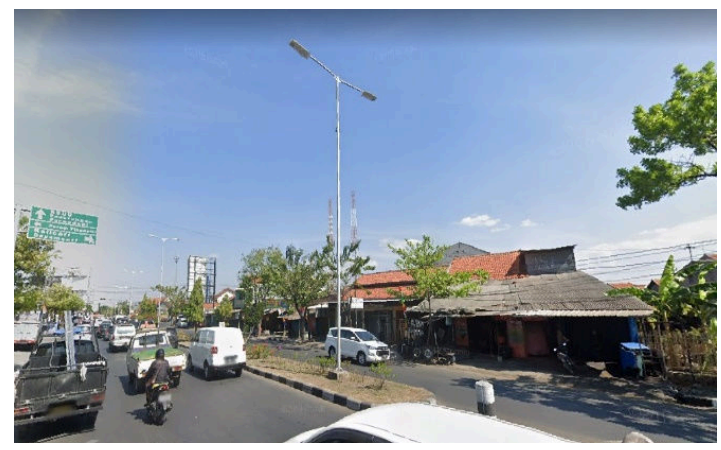

Sumber : Google Earth, 2021

\section{Gambar 1. Jalan Arteri Soekarno Hatta}

- Kawasan Perdagangan dan Jasa

Jika dilihat secara keseluruhan Kawasan Tlogosari memang memiliki potensi di bidang perdagangan dan jasa, oleh karna itu dijalan tersebut sering sekali terjadi macet di siang maupun malam hari. Banyak terdapat ruko-ruko bangunan maupun warung-warung makan yang tersedia yang menjual semua keperluan sehari-hari masyarakat sekitar. Jalan tersebut letaknya berada di jalan Tlogosari Raya 1 dan Jalan Tlogosari Raya 2. Sedangkan pada malam hari di pinggir jalan tersebut biasanya ramai akan pedagang kaki lima yang berjualan di sisi-sisi trotoar yang tersedia, hal ini pun juga bisa memperparah kemacetan di Kawasan Tlogosari, karena banyaknya pembeli yang memarkirkan kendaraanya sembarangan sehingga jalan raya yang seharusnya dijadikan tempat lalu lalang kendaraan sering terhalang dan terpotong oleh kendaraan yang parkir sembarangan.

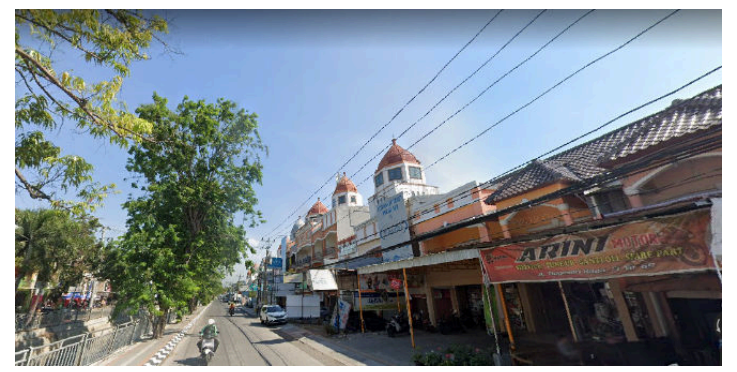

Sumber : Google Earth, 2021

\section{Gambar 2. Kawasan perdagangan dan jasa}

- Kawasan Pendidikan

Selain sebagai pusat perdagangan dan jasa, Kawasan Tlogosari Semarang juga sebagai kawasan pendidikan, di mana di sana terdapat beberapa perguruan tinggi yang letaknya tepat di arteri jalan Soekarno Hatta. Bukan cuma perguruan tinggi, di sekitar 
Kawasan Tlogosari pun juga banyak sarana pendidikan lainnya, mulai dari sekolah dasar sampai sekolah menengah atas maupun pesantren juga tersedia di Kawasan Tlogosari Semarang. Oleh karena itu biasanya di jam berangkat sekolah dan di jam pulang sekolah jalan di sekitar kawasan pendidikan tersebut sering macet karna memang aktivitas pelajar yang berangkat maupun pulang menuju ke rumahnya masing-masing, ditambah memang kawasannya juga memang sering ramai oleh pengguna jalan lainnya.

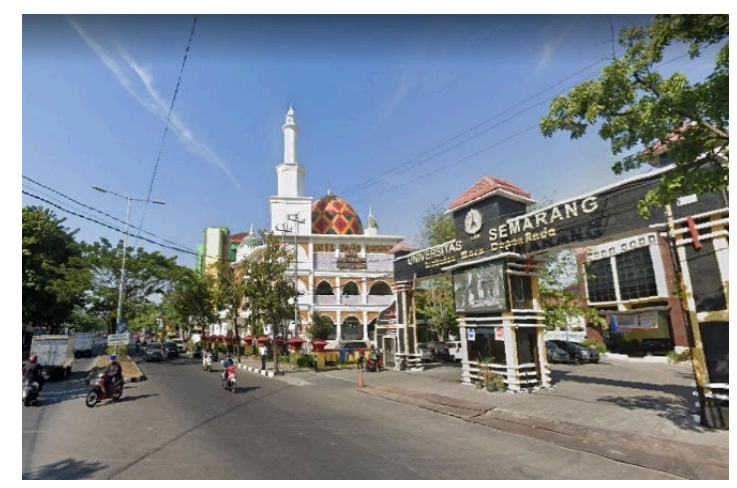

Sumber : google earth, 2021

\section{Gambar 3. Sarana Pendidikan}

Karena itu terdapat beberapa hal yang mungkin akan terjadi akibat kemacetan, yaitu :

- Polusi udara

Kemacetan yang parah juga bisa membuat terjadinya polusi udara yang berlebihan yang berasal dari asap kendaraan dari pengguna jalan tersebut, poulsi udara yang berlebihan tentunya dapat mengganggu kesehatan bagi masyarakat.

- Kerugian Waktu

Hal ini bisa saja terjadi jika macet yang terjadi memakan waktu lama, tentunya menyebabkan kerugian waktu bagi para pengguna jalan yang akan melakukan kegiatan sehari-harinya. Untuk menghindari hal tersebut jika ingin berpergian segera bisa melakukan perjalanan di jam-jam yang jarang terjadinya kemacetan.

- Pemborosan ekonomi

Faktor ini bisa saja terjadi jika macet terlalu lama dan para pengguna jalan tidak mematikan kendaraanya saat kemacetan berlangsung, maka hal tersebut bisa membuat pemborosan bahan bakar minyak di bandingkan orang yang tidak mengalami kemacetan ataupun mematikan kendaraan disaat kondisi macet terjadi.

Karna akibat tersebut terdapat beberapa hal yang mungkin bisa dilakukan untuk mengurangi kemacetan yang terjadi di Kawasan Tlogosari Semarang, yaitu :

- Pelebaran Jalan 
Solusi yang mungkin bisa dilakukan untuk mengurasi kondisi kemacetan adalah dengan melalukan beberapa pelebaran jalan pada jalan-jalan tertentu. Misalnya pada jalan yang cukup sempit di daerah yang padat akan aktivitas penduduk sehingga akan ada sedikit ruang yang cukup saat kemacetan jika pelebaran jalan dilakukan.

- Menyediakan lahan parkir

Hal ini bisa dilakukan untuk mengurangi kemacetan karena masih banyak pengguna jalan yang parkir sembarangan akibat kurang ataupun tidak tersedianya lahan parkir yang memadai.

- Merelokasi pedagang kaki lima

Karena banyaknya jumlah pedagang kaki lima yang biasanya berjualan di sepanjang trotoar jalan hal itu juga menambah kondisi kemacetan, dengan merelokasikan para pedagang kaki lima tersebut masalah kemacetan dapat sedikit berkurang karna tidak menghalangi jalan yang seharusnya digunakan untuk pengguna lalu lintas.

\section{SIMPULAN}

Berdasarkan permasalahan kemacetan yang ada di Kawasan Tlogosari terdapat tiga faktor yang paling dominan yaitu karena lokasinya yang strategis, salah satu pusat perdagangan dan jasa yang cukup ramai, serta termasuk kawasan pendidikan mulai dari sekolah dasar sampai perguruan tinggi. Oleh karena itu perlu adanya penanganan untuk mengurangi permasalahan kemacetan tersebut seperti melakukan pelebaran jalan di beberapa jalan yang sempit, menyediakan lahan parkir, serta merelokasikan pedagang kaki lima, Namun tetap mempertahankan potensi-potensi yang sudah ada di Kawasan Tlogosari Semarang.

\section{REFERENSI}

Grigg, N. 1988. Infrastrucutre Engineering and Management, John Wiley \& Sons. Malik Andy A.M. (2011). Identifikasi Kemacetan Lalu Lintas Di Kawasan Paal 2 Dan Pusat Kota Manado. J urnal Sabua Vol.3, No.1: 19-25.

Sugiyono.2005, Memahami Penelitian Kualitatif. Bandung: CV. Alfabeta.

Yolanda, I. Y., \& Kartono, K. (2014). Analisis Kepadatan Lalu Lintas di Perlimaan Jalan (Studi Kasus di Jalan Soekarno Hatta-tlogosari-supriyadi-medoho). Jurnal Matematika, 3(4), 1-6.

Imanda, M. B., \& Rusdarti, R. (2020). Kebijakan dan Implementasi Program Relokasi PKL Kawasan Tlogosari Kota Semarang. Efficient: Indonesian Journal of Development Economics, 3(1), 616-624.

Susilo, D. A., Astuti, R. S., \& Priyadi, B. P. (2019). Analisis Peran Stakeholders Dalam Pengaturan dan Pembinaan Pedagang Kaki Lima. Jurnal Natapraja: Kajian Ilmu Administrasi Negara, 7(2), 245-258. 